\title{
Availability and Use of Woody Plant Resources in Two Areas of Caatinga in Northeastern Brazil
}

\author{
Madson Reis de Oliveira Trindade, Jomar Gomes \\ Jardim, Alejandro Casas, Natan Medeiros Guerra, \\ and Reinaldo Farias Paiva de Lucena
}

\section{Research}

\begin{abstract}
Traditional knowledge of woody plants from the vegetation type known as caatinga was documented in the rural communities of João Câmara, Rio Grande do Norte, and Remígio, Paraíba, in northeastern Brazil. The relationship between the species availability and their local importance or use value (the "ecological apparency hypothesis") was evaluated based on the calculation of three types of use value: $U V_{\text {general, }} U V_{\text {actual, }}$, and $U V_{\text {potential }}$. A phytosociological study was conducted using the point-centered quarter method for sampling 4000 individual plants in the two communities studied. Semi-structured ethnobotanical interviews about the use and human cultural role of plants were carried out with 92 local participants ( 49 women and 43 men). The correlation between ethnobotanical and phytosociological data was analyzed using the Spearman correlation coefficient. A total of 58 useful plant species, belonging to 42 genera of 18 plant families, was recorded in interviews. Through the phytosociological study, 30 species belonging to 22 genera and 12 families in João Câmara, and 34 species of 22 genera from nine families in Remígio, were recorded. The ecological apparency hypothesis was supported in João Câmara, which showed positive correlations between $\mathrm{UV}_{\text {general }}$ and dominance ( $\mathrm{rs}$ $=0.49 ; p<0.02)$ and $U V_{\text {actual }}$ and dominance $(r s=0.43 ; p$ $<0.04$ ), but not in Remígio. Analyzing the data per use categories showed that only the technology category exhibited a positive correlation between $U V_{\text {potential }}$ and dominance $(r s=0.60$; and $p<0.03)$. Ecological apparency could explain better the relationship between the local availability and the use value of the timber resources. The point-centered quarter method was efficient to test the ecological apparency hypothesis.
\end{abstract}

\section{Introduction}

During the last decades, ethnobotanists have developed a variety of methods for testing hypotheses about the dynamic interrelationships between traditional knowledge and use of natural resources and ecological, anthropological, and social issues using quantitative data (Lucena et al. 2012a). Several recent studies have analyzed the use profile of plant resources according to their availability in local forests. One of the most important theoretical statements on this issue is the hypothesis of ecological apparency, which has been explored by a number of authors in different parts of the world (Albuquerque \& Lucena 2005,

\section{Correspondence}

Madson Reis de Oliveira Trindade, Programa de Pós-Graduação em Ciências Biológicas, Universidade Federal do Rio Grande do Norte, Centro de Biociências, Natal, Rio Grande do Norte, BRAZIL.

Jomar Gomes Jardim,Programa de Pós-Graduação em Ciências Biológicas, Universidade Federal do Rio Grande do Norte, Centro de Biociências, Natal, Rio Grande do Norte, BRAZIL and Universidade Federal do Sul da Bahia, Instituto de Humanidades, Artes e Ciências, campus Jorge Amado, Itabuna, Bahia, BRAZIL.

Alejandro Casas, Instituto de Investigaciones en Ecosistemas y Sustentabilidad, Universidad Nacional Autónoma de México, Morelia, Michoacán, MEXICO.

Natan Medeiros Guerra, Reinaldo Farias Paiva de Lucena, Federal University from Paraíba State, Agricultural Sciences Center, Department of Phytotechnical and Environmental Sciences, Ethnoecology Laboratory, Areia City, Paraíba, BRAZIL.

Ethnobotany Research \& Applications 14:313-330 (2015) 
Cunha \& Albuquerque 2006, La Torre-Cuadros \& Islebe 2003, Phillips \& Gentry 1993a,b, Stagegaard et al. 2002).

The apparency hypothesis was first proposed by Fenny (1976) and Rhoades and Cates (1976) as a way of explaining the foraging patterns of herbivore insects in relation to the availability of particular plant species. Phillips and Gentry (1993a,b) adapted this hypothesis for ethnobotanical studies, presuming that humans would display similar patterns of behavior to foraging insects when gathering plant products. Lucena et al. (2012a) similarly reasoned that plants with higher abundance and dominance (higher apparency) are more collected and used for different purposes, just as plants with higher availability are more consumed by insects. For testing such a hypothesis in human populations, Phillips and Gentry (1993a, b) developed quantitative methods based on what they called "use value (UV)," which made possible an approach to measure the relative importance of species in relation to their local use. Through this approach, a use value may be assigned to each species based on several indicators, such as the number of mentions of the recognized uses by people interviewed, the number of uses mentioned, the frequency of use, or the amounts of the resource that are used. Several authors have explored the relationship between UV indexes and ecological parameters of vegetation used as indicators of ecological apparency. Albuquerque and Lucena (2005) discussed that the failure to differentiate between actual use (effective use) and potential use (a use maintained in the memory of people but not really carried out) may overestimate the pressure on species caused by their use.

In order to address this problem, Lucena et al. (2012a) suggested a new way to approach the study of UV based on a proposal developed by Rossato et al. (1999). This proposal considered the calculation of UV by distinguishing the "actual use" or the use of a plant species frequently required and used, from "potential use," which includes those species that rarely or never have been used by people interviewed, although they know they can be used. In addition, Lucena et al. (2012a) defined the general use as the sum of the actual and potential use values, which is equivalent to the UV as traditionally calculated in literature without distinguishing the different forms of use (Lucena et al. 2012b).

Most ethnobotanical studies testing an ecological apparency hypothesis have been conducted in Latin America (e.g., Balcázar 2012, Cunha \& Albuquerque 2006, Ferraz et al. 2006, Galeano 2000, Jiménez-Escobar \& RangelCh 2012, La Torre-Cuadros \& Islebe 2003, Lawrence et al. 2005, Lucena et al. 2007, 2012a,b, Mutchnick \& McCarthy 1997, Ribeiro 2013, Sousa 2011, Thomas et al. 2009), mainly in areas of tropical rain forest (Lucena et al. 2012a). The records of responses to ecological apparency in dry forests or other ecosystems are restricted to a few studies (Albuquerque et al. 2005, Ayantunde et al.
2009, Balcázar 2012, Ferraz et al. 2006, Lucena et al. 2007, 2012a,b, Ribeiro 2013, Tunholi 2013) and do not confirm the occurrence of a general pattern as found in tropical rain forests. The relationship between use and availability of plant resources in these studies ranges from positive to negative to nonexistent (Albuquerque \& Lucena 2005, Balcázar 2012, Lucena et al. 2007, 2012a,b, Ribeiro et al. 2013, Souza 2011). Additional research in dry forests is needed to test the breadth of applicability of the apparency hypothesis and to help us understand the differences hitherto observed in the utilization of plant resources in dry and moist forests.

In order to refine the characterization of plant resource use in Brazilian semi-arid forests, our study tested an ecological apparency hypothesis in areas of the tropical dry forest called caatinga.

\section{Regional context and study area}

Our study was conducted in the Brazilian states of Paraíba and Rio Grande do Norte, in the municipalities of Remígio and João Câmara, respectively (Figure 1). These areas were selected because their territories are originally formed by caatinga (dry forest) and facilities. Previous studies of our research group were made in this region, which facilitated the interaction with local people and vegetation sampling.

Caatinga is a biome predominantly composed by xerophilous, woody, and thorny vegetation and short-lived herbaceous plants (Costa et al. 2007). It exists exclusively in Brazil, where it covers $800,000 \mathrm{~km}^{2}$. Vegetation of caatinga is highly heterogeneous and, according to Velloso et al. (2002), it may be classified in eight ecogeographic zones: Complexo de Campo Maior, Complexo IbiapabaAraripe, Depressão Sertaneja Setentrional, Planalto da Borborema, Depressão Sertaneja Meridional, Dunas do São Francisco, Complexo da Chapada Diamantina, and Raso da Catarina.

The municipality of João Câmara (5³2'16"'S, 3549'12'W) is located in the meso-region of Agreste Potiguar, microregion Baixa Verde, in the Depressão Sertaneja Setentrional. It is the $14^{\text {th }}$ most populated municipality of Rio Grande do Norte, with 32,220 people, in a territory of $714,961 \mathrm{~km}^{2}$ at an average elevation of $160 \mathrm{~m}$ (IBGE 2010). The economy of the municipality is based on agriculture and the raising of livestock; its main products are maize, beans, manioc, cattle, goats, and sheep. According to data from IBGE, $53.17 \%$ of the population lived below the poverty line in 2003 (US $\$ 25.00 /$ month).

In the Depressão Sertaneja Setentrional, vegetation is predominantly shrubby-arboreal caatinga, $40-50 \%$ of which is designated for conservation. Soils are generally thin, stony, and particularly vulnerable to erosion. The climate is semi-arid; rainfall is generally concentrated in 3 to 
Trindade et al. - Availability and Use of Woody Plant Resources in Two Areas 315 of Caatinga in Northeastern Brazil

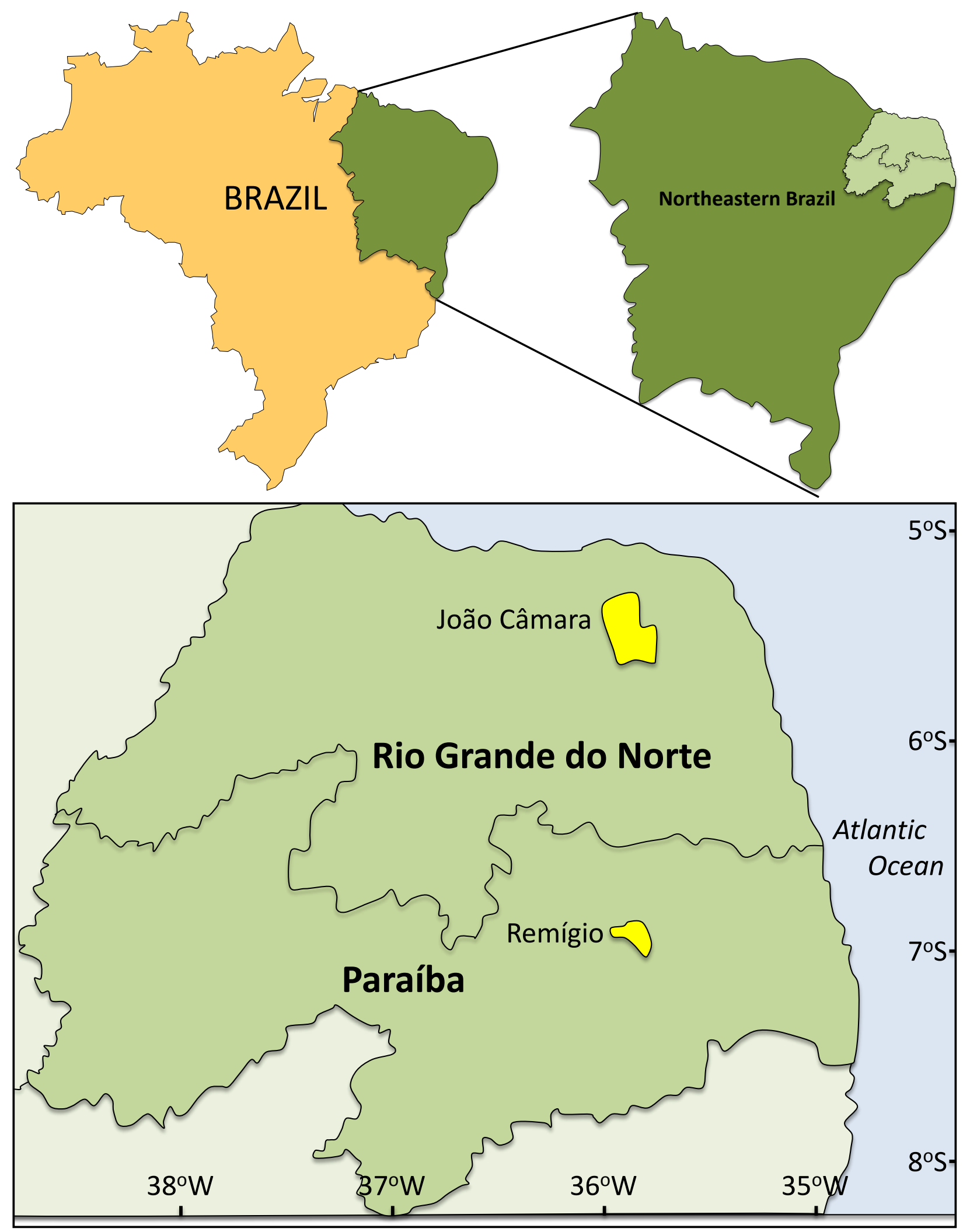

Figure 1. Location of the municipalities of João Câmara and Remígio in the states of Rio Grande do Norte and Paraíba, northeastern Brazil. 
5 months of the year, with annual precipitation of $640 \mathrm{~mm}$ and a high evaporation rate (1500-2000 mm/year). Annual mean temperature averages between 21 and $24.7^{\circ} \mathrm{C}$, with a maximum of $32^{\circ} \mathrm{C}$. Relative humidity is about $75 \%$ (Alves et al. 2009, Nimer 1989, Prado 2003, Velloso et al. 2002).

The community studied is part of the Mato Grande region, nearly $18 \mathrm{~km}$ from the main town. The Mato Grande comprises several small villages with few households: Cauaçu (14 households), Arisco do Sotero (15 households), Ubaíra (4 households), and Lagoa de São José (8 households). There is a small health center providing weekly basic clinic and odontological attention.

The municipality of Remígio is located in the meso-region of Agreste Paraibano, micro-region of Curimataú Oriental, within the eco-region of Planalto da Borborema. It is the $42^{\text {nd }}$ most populated municipality of Paraíba, with 17,581 people. Remígio is located at $06^{\circ} 54^{\prime} 10^{\prime \prime S}, 35^{\circ} 50^{\prime} 02^{\prime \prime} \mathrm{W}$, with a territory of $178,064 \mathrm{~km}^{2}$ at an elevation of $593 \mathrm{~m}$ (IBGE 2010). Its economy is based on agriculture, mainly plantations of maize, beans, and manioc, as well as raising of cattle and horses. Nearly $48 \%$ of the population lives under the limits of poverty (IBGE 2010). The municipality of Remígio has 34 schools attending 2651 students. Nearly 600 students study at the secondary school in the only municipal school available (IBGE 2012).

Vegetation in this region is similar to caatinga from Cariri Paraíbano, with spaced shrubby-arboreal composition (Velloso et al. 2002). Soils are predominantly granite mass, with variable depth and generally fertile, susceptible to erosion. Annual mean temperature is $25^{\circ} \mathrm{C}$, and the semiarid climate is dry and hot. The rainy season is from February to May, with annual rainfall varying from 400 to $650 \mathrm{~mm}$, or even higher in the coast where vegetation is tall forest. Yet according to Velloso et al. (2002), the ecoregion of Planalto da Borborema has high levels of degradation (>90\%), with scarce and diffuse patches of remaining native vegetation.

The community studied in Remígio was Coelho, which is $7 \mathrm{~km}$ from the center of the municipality. The community is composed of 80 persons mainly dedicated to household agriculture of maize and beans and raising of livestock.

\section{Methods}

\section{Phytosociological inventory}

In order to test our hypothesis, a phytosociological inventory was conducted in fragments of vegetation close to the communities, recording all species considered useful by local people. A point-centered quarter method described by Cottam and Curtis (1956) was chosen as an alternative to the widely-used plot method for measuring diversity in forests because the former makes more efficient use of time and a small research team in sampling large areas. The localities studied were mentioned by local people identified as areas that they use to collect plants; therefore, transects were sampled in areas within a radius of $5 \mathrm{~km}$ around the communities. All transects were placed in parallel to each other, separated by a distance of $10 \mathrm{~m}$. A total of 100 transects with $100 \mathrm{~m}$ each in length (50 transects per community) were sampled. Every 10 $\mathrm{m}$ along transects a point was marked. The area around each point was divided into four $90^{\circ}$ quadrants, and the four woody plants (described below) closest to the point in each quadrant were sampled, so that each point acted as the center of the four quadrants (Figure 2).

All individual plants with height $\geq 1 \mathrm{~m}$ and diameter $\geq 3 \mathrm{~cm}$ were measured from the soil level. A total of 4000 individual plants were sampled, and each type was collected and prepared as an herbarium specimen. All specimens were identified by comparing with specimens previously identified and deposited in the herbarium EAN at the Universidade Federal da Paraiba, Campus III - CCA, and UFRN at the Universidade Federal do Rio Grande do Norte. Any specimens considered particularly difficult to identify were reviewed by botanical specialists. All specimens were then deposited in EAN and UFRN.

The following phytosociological data were recorded: basal area, importance value, relative density, relative dominance, and relative frequency, which were then analyzed following Araújo and Ferraz (2010). The relative density (RtD, \%) was estimated by dividing the number of individual plants of a taxon observed by the total number of individual plants sampled. The relative frequency (RtF, \%) was estimated by dividing the absolute frequency (Fat) of a species within the plot by the total frequency (TF, \%, the sum of all absolute frequencies). The relative dominance (RtDo, \%) is the percentage of the absolute dominance (ADo) of a species in relation to the total dominance (TDo).

\section{Ethnobotanical survey}

Semi-structured interviews were conducted with local people following methods recommended by Albuquerque et al. (2006). These semi-structured interviews allow researchers to gather a great deal of information from a large number of people in a relatively short time. The questions included knowledge about the use of tree species native to the region. Prior to the interviews, the aims of the study were explained to all participants, who signed a Terms of Consent Free and Clarified, according to requisites established by Health National Council through the Ethics in Research Committee, Resolution 196/96. This research was approved by the Committee of Ethics in Research with Human Beings of the Hospital Lauro Wanderley of the Universidade Federal da Paraíba and by the Ethics Committee of the Universidade Federal do Rio Grande do Norte. 


\section{Trindade et al. - Availability and Use of Woody Plant Resources in Two Areas 317 of Caatinga in Northeastern Brazil}

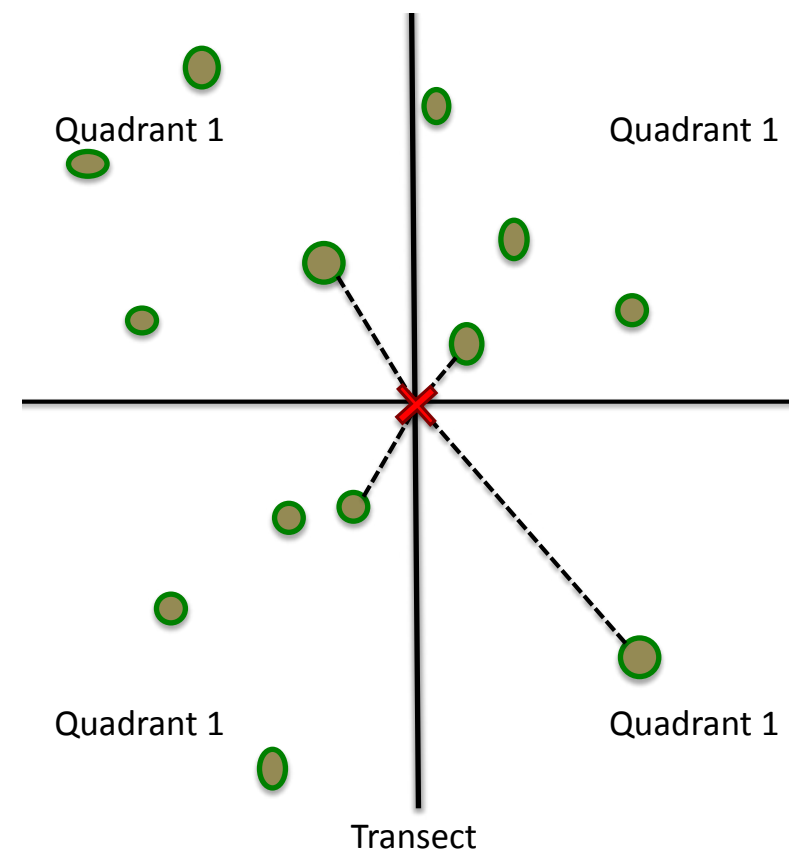

Figure 2. The point-centered quarter method. The area around the point (red " $x$ ") is divided into four $90^{\circ}$ quarters. The green circles (represent the trees) closest to the point are sampled.

A total of 92 persons were interviewed. These persons were chosen considering their role as family heads. In João Câmara 50 persons participated (25 men and 25 women), whereas in Remígio 42 persons participated (18 men and 24 women).

The "guided trip" technique, described by Spradley and McCurdy (1972), was used in both localities with the guid- ance of key informants selected by consensus of the local people based on the recognition of their ability to identify plants. This technique, widely used in ethnobotanical research, makes possible identification of ethno-species mentioned during the interviews, thus helping to minimize errors in botanical collecting and the time invested in that research phase. A total of five guided trips were carried out per community, each guided by different persons.

Plant species recorded in the interviews were grouped in use categories according to Ferraz et al. (2006) and Lucena et al. (2008). The definition of categories of use of the plant resources was based on the considerations of Lucena et al. (2012 a,b), reproduced in Table 1.

\section{Data analysis}

\section{Phytosociological data}

The relationship between the UV for each species mentioned in interviews and availability of each plant in forest (phytosociological parameters) were tested using the Spearman correlation coefficient using the program BioEstat 5.0 (Ayres et al. 2007) because data did not approach normality.

Phytosociological parameters (basal area, relative dominance, relative frequency, and relative density) were calculated using the software Fitopac 2.1 (Shepherd 2009), and related with data about use value of the species (UVgeneral, $U V_{\text {potential, }}$ and $\left.U V_{\text {actual }}\right)$. This method was also used in other studies that tested the apparency hypothesis (Lucena et al. 2012 a,b, Ribeiro et al. 2014).

In order to test the relation between use values and local availability of plant species, only the native woody species with use referred to by people was considered and also those plants recorded in phytosociological study. Conse-

Table 1. Plant use categories (Lucena et al. 2008).

\begin{tabular}{|l|l|l|}
\hline 1 & Food & Fruit, seeds, and roots consumed by humans. \\
\hline 2 & Fuel & Plants used as fuel wood or coal for direct use or commercialization. \\
\hline 3 & Construction & Plants used in construction of houses, fences, doors, and other constructions. \\
\hline 4 & Fodder & Plants used for feeding domestic animals. \\
\hline 5 & Magic-religious & $\begin{array}{l}\text { Plants of cultural importance, used as indicators or predictors, or for praying and treating spiri- } \\
\text { tual illnesses. }\end{array}$ \\
\hline 6 & Medicinal & Plants used for treating human pains and illnesses. \\
\hline 7 & Ornamental & Plants cultivated as ornaments. \\
\hline 8 & Other uses & Including those for personal hygiene (hair washing, teeth brushing, etc.) and shade \\
\hline 9 & Technological & $\begin{array}{l}\text { A wide category, including plants used to elaborate tools such as wood handles for machetes, } \\
\text { shoes, hammer, pickaxes, and others, yokes, wood spoons, pestles, brooms, furniture, bul- } \\
\text { let cases of a shotgun. }\end{array}$ \\
\hline 10 & Poison-abortive & Plants used for these purposes. \\
\hline 11 & Veterinary & Plants used to treat animals. \\
\hline
\end{tabular}


quently, similarity among areas was analyzed using the binary coefficient of Jaccard (Araújo \& Ferraz 2010).

\section{Ethnobotanical data}

A limitation to the traditional calculation of the use value is lack of distinction of multiple utilities within a single use category. To address this, all the different applications of uses were differentiated for all species used in communities. For example a plant used for food but with different forms of consumption was considered within each form of use as a different use (juice, jelly, using fresh, seasoning, etc.). In this way the plants would not be assessed as having a single utility and thus present low scores.

All species recorded in our ethnobotanical study were assigned a use value according to the formula: UV $=\sum U i / n$, in which $\mathrm{Ui}=$ number of uses mentioned per informant and $n=$ total number of informants (Rossato et al. 1999). The use categories also had a use value calculated as $U V c=\sum U V / n c$, where UVc = use value of each species per use category and $\mathrm{nc}=$ number of species belonging to that category. In this study we distinguished citations referring to the actual and potential use for the calculation of the UV, according to the proposal developed by
Lucena et al. (2012). The UV actual $_{\text {was }}$ calculated using a single species with the higher use frequency (effectively used), whereas UV $V_{\text {potential }}$ makes reference to citations to potential uses (species of known utility but rarely used), and the UV $\mathrm{U}_{\text {general }}$ makes use of all citations either actual or potential. Thus, the differences in how people make use of native plants are identified. In this way it is possible to distinguish the forest species that are actually used from those in which only utility knowledge occurs. The Pearson correlation coefficient was used to compare relations between use values ( $U V_{\text {general }}, U V_{\text {actual }}$, and $\left.U V_{\text {potential }}\right)$.

\section{Results}

\section{Phytosociological parameters}

A total of 30 species were identified, distributed in 23 genera and 12 families of woody plants in João Câmara; 23 species were considered useful by local people (Table 2). In Remígio 34 species belonging to 22 genera of nine families were identified, 20 of them being useful (Table 3 ). The Jaccard coefficient indicated floristic similarity of about $35 \%$ to $41 \%$ between the areas, considering only useful species. These species have wide distribution in

Table 2. Phytosociological and ethnobotanical parameters of the species used in João Câmara, Rio Grande do Norte, Brazil, available in the studied forest fragment.

\begin{tabular}{|c|c|c|c|c|c|c|c|}
\hline Family & Species & 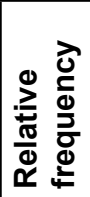 & 总 & 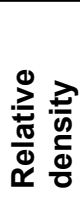 & $3^{\overline{\frac{\pi}{\omega}}}$ & $3^{\frac{\bar{J}}{\tilde{J}}}$ & 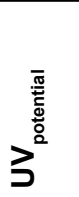 \\
\hline \multirow[t]{2}{*}{ Anacardiaceae } & Myracrodruon urundeuva Allemão & 0.15 & 0.09 & 0.10 & 0.84 & 0.68 & 0.16 \\
\hline & Spondias tuberosa Arruda & 0.08 & 0.03 & 0.05 & 2.48 & 2.12 & 0.36 \\
\hline Apocynaceae & Aspidosperma pyrifolium Mart. & 6.63 & 4.63 & 5.85 & 2.48 & 2.06 & 0.42 \\
\hline Burseraceae & Commiphora leptophloeos (Mart.) J.B.Gillet & 1.83 & 4.52 & 1.20 & 0.96 & 0.68 & 0.28 \\
\hline \multirow[t]{2}{*}{ Capparaceae } & Cynophalla flexuosa (L.) J.Prese & 5.03 & 1.98 & 3.85 & 0.30 & 0.18 & 0.12 \\
\hline & Neocalyptrocalyx longifolium (Mart.) Cornejo \& Iltis & 2.52 & 1.09 & 1.75 & 0.68 & 0.20 & 0.48 \\
\hline Combretaceae & Combretum leprosum Mart. & 0.08 & 0.03 & 0.05 & 0.02 & 0.00 & 0.02 \\
\hline \multirow[t]{4}{*}{ Euphorbiaceae } & Croton blanchetianus Baill & 24.3 & 14.7 & 35.2 & 1.68 & 1.40 & 0.28 \\
\hline & Jatropha mollissima (Pohl) Baill. & 2.13 & 0.61 & 1.55 & 0.58 & 0.40 & 0.18 \\
\hline & Manihot carthaginensis (Jacq.) Müll.Arg. & 0.76 & 0.51 & 0.50 & 0.16 & 0.08 & 0.08 \\
\hline & Sapium glandulosum (L.) Morong & 1.91 & 4.78 & 1.30 & 0.16 & 0.04 & 0.12 \\
\hline \multirow[t]{7}{*}{ Fabaceae } & Amburana cearensis (Allemão) A.C.Sm. & 0.61 & 2.17 & 0.45 & 0.86 & 0.76 & 0.10 \\
\hline & Anadenanthera colubrina (Vell.) Brenan & 1.75 & 1.47 & 1.35 & 0.62 & 0.46 & 0.16 \\
\hline & Bauhinia cheilantha (Bong.) Steud. & 4.65 & 1.60 & 4.25 & 0.66 & 0.44 & 0.22 \\
\hline & Chloroleucon acacioides (Ducke) Barneby \& J.W.Grimes & 1.30 & 0.69 & 0.95 & 0.08 & 0.08 & 0.00 \\
\hline & Libidibia ferrea (Mart. ex Tul.) L.P.Queiroz & 1.14 & 2.18 & 0.80 & 0.78 & 0.48 & 0.30 \\
\hline & Mimosa caesalpiniifolia Benth. & 0.61 & 0.36 & 0.40 & 0.54 & 0.40 & 0.14 \\
\hline & Mimosa tenuiflora (Willd.) Poir. & 10.4 & 25.1 & 9.50 & 2.78 & 2.50 & 0.28 \\
\hline
\end{tabular}




\section{Trindade et al. - Availability and Use of Woody Plant Resources in Two Areas 319 of Caatinga in Northeastern Brazil}

\begin{tabular}{|c|c|c|c|c|c|c|c|}
\hline Family & Species & 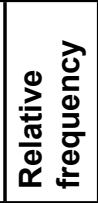 & 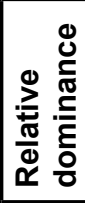 & 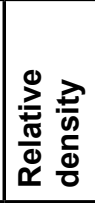 & $3^{\frac{5}{50}}$ & $3^{\frac{\bar{g}}{\tilde{c}}}$ & 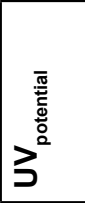 \\
\hline \multirow[t]{3}{*}{ Fabaceae } & Piptadenia stipulacea (Benth.) Ducke & 7.32 & 7.17 & 7.25 & 0.14 & 0.06 & 0.08 \\
\hline & Pithecellobium diversifolium Benth. & 0.53 & 0.23 & 0.35 & 0.08 & 0.08 & 0.00 \\
\hline & Poincianella pyramidalis (Tul.) L.P.Queiroz & 14.0 & 15.5 & 13.0 & 1.28 & 0.98 & 0.30 \\
\hline Rhamnaceae & Ziziphus joazeiro Mart. & 4.42 & 6.75 & 3.10 & 1.80 & 1.00 & 0.80 \\
\hline Sapotaceae & Sideroxylon obtusifolium (Roem \& Schult.) T.D.Penn. & 0.53 & 0.37 & 0.35 & 1.56 & 1.14 & 0.42 \\
\hline
\end{tabular}

the forest, with the exception of pereiro, which is more frequent in sites distant to the community.

Several species with $U_{\text {actual }}$ are barely represented in the phytosociological sampling in João Câmara-for example, angico (Anadenanthera colubrina (Vell.) Brenan - 27 individuals), imburana (Commiphora leptophloeos (Mart.) J.B.Gillett - 24 inds.), cumarú (Amburana cearensis (Allemao) A.C.Sm. -9 inds.), quixabeira (Sideroxylon obtusifolium (Roem. \& Schult.) T.D.Penn. -7 inds.), and aroeira (Myracrodruon urundeuva Allemão - 2 inds.). In Remígio these were the cases of jurema-preta (Mimosa tenuiflora (Willd.) Poir. - 7 inds.), ameixa (Ximenia americana L. -4 inds.), jucá (Libidibia ferrea (Mart. ex Tul.) L.P.Queiroz - 2 inds.), and baraúna (Schinopsis brasiliensis Engl. - 2 inds.), which were recorded only in areas distant to the community.

Some species were not represented in the phytosociological sampling, although they are important for the com-

Table 3. Phytosociological and ethnobotanical parameters of the species used in Remígio, Paraíba, Brazil, available in the studied forest fragment.

\begin{tabular}{|c|c|c|c|c|c|c|c|}
\hline Family & Species & 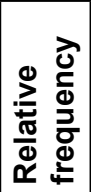 & 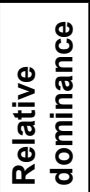 & 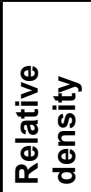 & $3^{\frac{\pi}{\sqrt{5}}}$ & $3^{\frac{\pi}{\tilde{I}}}$ & $3^{\frac{\bar{\pi}}{\overline{\underline{E}}}}$ \\
\hline \multirow[t]{3}{*}{ Anacardicaceae } & Myracrodruon urundeuva Allemão & 0.53 & 0.90 & 0.35 & 2.12 & 1.29 & 0.83 \\
\hline & Schinopsis brasiliensis Engl. & 0.15 & 0.02 & 0.10 & 3.33 & 1.50 & 1.83 \\
\hline & Spondias tuberosa Arruda & 0.15 & 0.80 & 0.10 & 1.52 & 1.07 & 0.45 \\
\hline Burseraceae & Commiphora leptophloeos (Mart.) J.B.Gillet & 0.53 & 0.54 & 0.35 & 1.14 & 0.60 & 0.55 \\
\hline Capparaceae & Cynophalla flexuosa (L.) J.Prese & 0.60 & 1.10 & 0.40 & 0.98 & 0.40 & 0.57 \\
\hline Combretaceae & Thiloa glaucocarpa (Mart.) Eichler & 0.30 & 0.37 & 0.25 & 0.33 & 0.17 & 0.17 \\
\hline \multirow[t]{5}{*}{ Euphorbiaceae } & Croton blanchetianus Baill & 20.8 & 19.6 & 28.5 & 2.31 & 1.38 & 0.93 \\
\hline & Jatropha mollissima (Pohl) Baill. & 7.00 & 2.58 & 6.80 & 0.24 & 0.17 & 0.07 \\
\hline & Mallotus rhamnifolius (Willd.) Müll.Arg. & 6.17 & 2.03 & 5.45 & 0.07 & 0.07 & 0.00 \\
\hline & Manihot dichotoma Ule & 0.60 & 0.40 & 0.67 & 0.79 & 0.45 & 0.33 \\
\hline & Sapium lanceolatum (Müll.Arg.) Huber & 1.05 & 1.29 & 0.75 & 3.33 & 1.50 & 1.83 \\
\hline \multirow[t]{7}{*}{ Fabaceae } & Bauhinia cheilantha (Bong.) Steud. & 0.83 & 0.69 & 0.65 & 0.83 & 0.45 & 0.38 \\
\hline & Libidibia ferrea (Mart. ex Tul.) L.P.Queiroz & 0.15 & 0.29 & 0.10 & 1.10 & 0.38 & 0.71 \\
\hline & Luetzelburgia sp. & 0.08 & 0.10 & 0.05 & 0.14 & 0.02 & 0.12 \\
\hline & Mimosa tenuiflora (Willd.) Poir. & 0.53 & 0.17 & 0.35 & 1.98 & 1.02 & 0.95 \\
\hline & Piptadenia stipulaceae (Benth.) Ducke & 8.28 & 8.02 & 8.30 & 0.02 & 0.00 & 0.02 \\
\hline & Poincianella pyramidalis (Tul.) L.P.Queiroz & 14.3 & 24.4 & 12.1 & 3.45 & 2.29 & 1.17 \\
\hline & Senna martiana (Benth.) H.S.Irwin \& Barneby & 3.16 & 1.92 & 2.80 & 0.36 & 0.17 & 0.19 \\
\hline Olacaceae & Ximenia americana L. & 0.23 & 0.22 & 0.20 & 0.29 & 0.19 & 0.10 \\
\hline Rhamnaceae & Ziziphus joazeiro Mart. & 5.42 & 14.4 & 4.50 & 3.98 & 1.93 & 2.05 \\
\hline
\end{tabular}




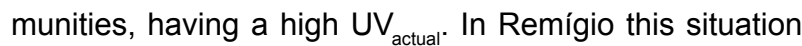
was appreciated in the following species: $A$. cearensis, $A$. colubrina, A. pyrifolium, Crataeva tapia L., Handroanthus impetiginosus (Mart. ex DC.) Mattos, and S. obtusifolium. In João Câmara these were the cases of Croton zehntneri Pax \& K.Hoffm., C. tapia, Eugenia flavescens DC., and $X$. americana. In the apparency test, these species were discarded because they did not have phytosociological records, as well as those species that were recorded in vegetation but were not considered important by people.

\section{Ethnobotanical inventory}

59 useful species were referred to and described in both communities. These species belong to 22 families and 49 genera. All species and their respective UV are listed in Tables 3 and 4.

In João Câmara people participating in the research mentioned 38 woody species belonging to 39 genera and 18 families (Table 4). These species were classified into nine use categories, and each species may be included in more than one category. The three use categories with more than 20 species were medicinal (30 species), technological (28), and construction (22) (Figure 3).

In Remígio, 37 species of 37 genera and 19 families were considered useful by people interviewed (Table 5). These species were grouped into 11 use categories, the richer with more than 17 species each being construction (25

Table 4. General list of identified useful species with their respective uses values in João Câmara, Rio Grande do Norte, Brazil.

\begin{tabular}{|c|c|c|c|c|}
\hline Species & Common name & $U_{\text {general }}$ & $\mathbf{U V}_{\text {actual }}$ & $\mathbf{U V}_{\text {potential }}$ \\
\hline \multicolumn{5}{|l|}{ Anacardiaceae } \\
\hline Myracrodruon urundeuva Allemão & Aroeira & 0.84 & 0.68 & 0.16 \\
\hline Spondias tuberosa Arruda & Umbu & 2.48 & 2.12 & 0.36 \\
\hline \multicolumn{5}{|l|}{ Apocynaceae } \\
\hline Aspidosperma pyrifolium Mart. & Pereiro & 2.48 & 2.06 & 0.42 \\
\hline \multicolumn{5}{|l|}{ Arecaceae } \\
\hline Copernicia prunifera (Mill.) H.E.Moore & Carnaúba & 0.16 & 0.12 & 0.04 \\
\hline Syagrus cearensis Noblick & Catolé & 0.18 & 0.08 & 0.10 \\
\hline \multicolumn{5}{|l|}{ Bignoniaceae } \\
\hline Handroanthus impetiginosus (Mart. ex DC.) Mattos & Pau-d'arco & 0.2 & 0.08 & 0.12 \\
\hline Tabebuia aurea (Silva Manso) Benth. \& Hook.f. ex S.Moore & Craíba & 0.02 & 0.02 & 0.00 \\
\hline \multicolumn{5}{|l|}{ Burseraceae } \\
\hline Commiphora leptophloeos (Mart.) J.B.Gillet & Imburana & 0.96 & 0.68 & 0.28 \\
\hline \multicolumn{5}{|l|}{ Capparaceae } \\
\hline Crataeva tapia L. & Trapiá & 0.76 & 0.26 & 0.5 \\
\hline Cynophalla flexuosa (L.) J.Prese & Feijão-bravo & 0.3 & 0.18 & 0.12 \\
\hline Neocalyptrocalyx longifolium (Mart.) Cornejo \& Iltis & Incó & 0.68 & 0.2 & 0.48 \\
\hline \multicolumn{5}{|l|}{ Celastraceae } \\
\hline Maytenus rigida Mart. & Bom-nome & 0.36 & 0.3 & 0.06 \\
\hline \multicolumn{5}{|l|}{ Combretaceae } \\
\hline Combretum leprosum Mart. & Mufumbo & 0.02 & 0.00 & 0.02 \\
\hline \multicolumn{5}{|l|}{ Euphorbiaceae } \\
\hline Cnidoscolus quercifolius Pohl & Favela & 0.04 & 0.00 & 0.04 \\
\hline Croton blanchetianus Baill. & Marmeleiro & 1.68 & 1.40 & 0.28 \\
\hline Croton zehntneri Pax \& K.Hoffm. & Canelinha-do-mato & 1.18 & 1.14 & 0.04 \\
\hline Jatropha mollissima (Pohl) Baill. & Pião-bravo & 0.58 & 0.40 & 0.18 \\
\hline
\end{tabular}


Trindade et al. - Availability and Use of Woody Plant Resources in Two Areas 321 of Caatinga in Northeastern Brazil

\begin{tabular}{|c|c|c|c|c|}
\hline Species & Common name & $\mathbf{U V}_{\text {general }}$ & $\mathbf{U V}_{\text {actual }}$ & $U_{\text {potential }}$ \\
\hline Manihot carthaginensis (Jacq.) Müll.Arg. & Maniçoba & 0.16 & 0.08 & 0.08 \\
\hline Sapium glandulosum (L.) Morong & Burra-leiteira & 0.16 & 0.04 & 0.12 \\
\hline \multicolumn{5}{|l|}{ Fabaceae } \\
\hline Amburana cearensis (Allemão) A.C.Sm. & Cumaru & 0.86 & 0.76 & 0.1 \\
\hline Anadenanthera colubrina (Vell.) Brenan & Angico & 0.62 & 0.46 & 0.16 \\
\hline Bauhinia cheilantha (Bong.) Steud. & Mororó & 0.66 & 0.44 & 0.22 \\
\hline Bauhinia sp. & Mororó-sem-espinho & 0.04 & 0.00 & 0.04 \\
\hline Chloroleucon acacioides (Ducke) Barneby \& J.W.Grimes & Espinheiro-branco & 0.08 & 0.08 & 0 \\
\hline Erythrina velutina Willd. & Mulungú & 0.06 & 0.02 & 0.04 \\
\hline Libidibia ferrea (Mart. ex Tul.) L.P.Queiroz & Jucá & 0.78 & 0.48 & 0.3 \\
\hline Mimosa caesalpiniifolia Benth. & Sabiá & 0.54 & 0.40 & 0.14 \\
\hline Mimosa sp. & Jurema-branca & 0.14 & 0.06 & 0.08 \\
\hline Mimosa tenuiflora (Willd.) Poir. & Jurema-preta & 2.78 & 2.50 & 0.28 \\
\hline Pityrocarpa moniliformis (Benth.) Luckow \& R.W.Jobson & Catanduba & 0.26 & 0.14 & 0.12 \\
\hline Piptadenia sp. & Sajadeira & 0.02 & 0.00 & 0.02 \\
\hline Poincianella pyramidalis (Tul.) L.P.Queiroz & Catingueira & 1.28 & 0.98 & 0.30 \\
\hline Senegalia sp. & Vela-branca & 0.10 & 0.02 & 0.08 \\
\hline Senna spectabilis (DC.) H.S.Irwin \& Barneby & Canafístula & 0.14 & 0.10 & 0.04 \\
\hline \multicolumn{5}{|l|}{ Malvaceae } \\
\hline Ceiba glaziovii (Kuntze) K.Schum & Barriguda & 0.12 & 0.06 & 0.06 \\
\hline \multicolumn{5}{|l|}{ Meliaceae } \\
\hline Cedrela odorata L. & Cedro & 0.04 & 0.00 & 0.04 \\
\hline \multicolumn{5}{|l|}{ Myrtaceae } \\
\hline Campomanesia sp. & Guabiraba & 0.06 & 0.04 & 0.02 \\
\hline Eugenia flavescens DC. & Ubaia & 0.54 & 0.28 & 0.26 \\
\hline Unidentified & Cambuim & 0.02 & 0.02 & 0.00 \\
\hline \multicolumn{5}{|l|}{ Olacaceae } \\
\hline Ximenia americana L. & Ameixa & 1.64 & 1.42 & 0.22 \\
\hline \multicolumn{5}{|l|}{ Rhamnaceae } \\
\hline Ziziphus joazeiro Mart. & Juá & 1.80 & 1.00 & 0.80 \\
\hline \multicolumn{5}{|l|}{ Rubiaceae } \\
\hline Coutarea hexandra (Jacq.) K.Schum. & Quina-quina & 0.14 & 0.12 & 0.02 \\
\hline \multicolumn{5}{|l|}{ Rutaceae } \\
\hline Dictyoloma vandellianum A.Juss. & Sabugueira & 0.1 & 0.08 & 0.02 \\
\hline \multicolumn{5}{|l|}{ Sapotaceae } \\
\hline Sideroxylon obtusifolium (Roem \& Schult.) T.D.Penn. & Quixabeira & 1.56 & 1.14 & 0.42 \\
\hline
\end{tabular}

species), technological (24), fuel (23), and medicinal (23) (Figure 3).

In relation to the number of citations of uses, the three use categories with more $U_{\text {actual }}$ citations in João Câmara were medicinal 328 (67 potential), construction 222 (45 potential), and food 199 citations (105 potential). In Remí- gio the more important were construction 210 (167 potential), fuel 209 (149 potential), and technological 169 (179 potential) (Figure 4). The category for timber had higher representation, which indicates that wood is the plant part of interest, mainly because it is available throughout the whole year, not being affected by the drastic seasonality characteristic of caatinga. 


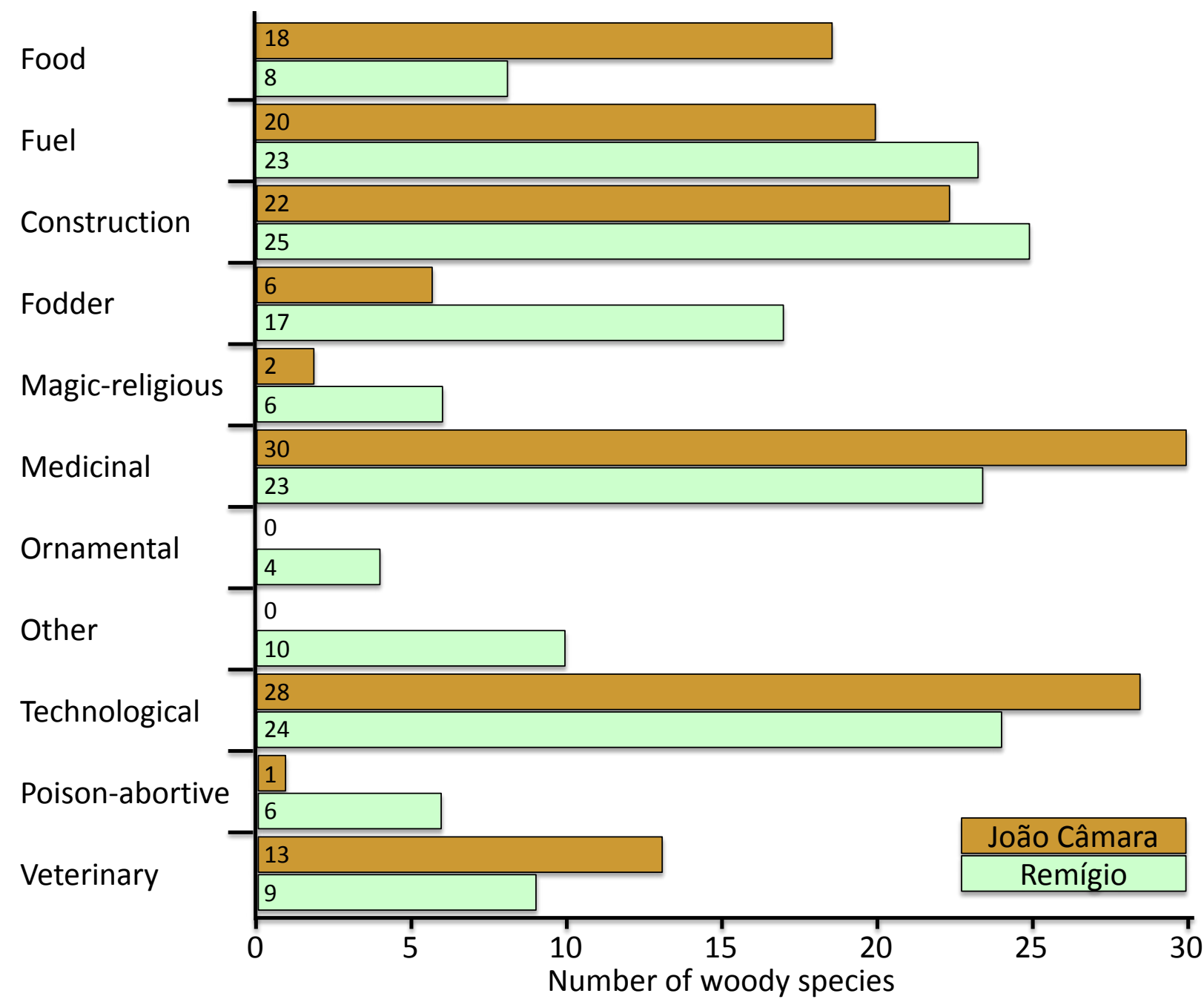

Figure 3. Number of woody species in each use category in the community of Mato Grande (municipality of João Câmara, Rio Grande do Norte) and Coelho (municipality of Remígio, Paraíba), northeastern Brazil.

Table 5. General list of identified useful species with their respective uses values in Remígio, Paraíba, Brazil.

\begin{tabular}{|c|c|c|c|c|}
\hline Species & Common name & UV $_{\text {general }}$ & $\mathbf{U V}_{\text {actual }}$ & $\mathbf{U V}_{\text {potential }}$ \\
\hline \multicolumn{5}{|l|}{ Anacardiaceae } \\
\hline Myracrodruon urundeuva Allemão & Aroeira & 2.12 & 1.29 & 0.83 \\
\hline Schinopsis brasiliensis Engl. & Baraúna & 3.33 & 1.5 & 1.83 \\
\hline Spondias tuberosa Arruda & Umbu & 1.52 & 1.07 & 0.45 \\
\hline \multicolumn{5}{|l|}{ Apocynaceae } \\
\hline Aspidosperma pyrifolium Mart. & Pereiro & 4.86 & 2.98 & 1.88 \\
\hline \multicolumn{5}{|l|}{ Bignoniaceae } \\
\hline Handroanthus impetiginosus (Mart. ex. DC.) Mattos & Pau-d'arco-roxo & 1.10 & 0.45 & 0.64 \\
\hline Tabebuia aurea (Silva Manso) Benth. \& Hook.f. ex S.Moore & Craibeira & 0.17 & 0.00 & 0.17 \\
\hline Tabebuia serratifolia (Vahl) G.Nichols. & Pau-d'arco-amarelo & 0.67 & 0.31 & 0.36 \\
\hline \multicolumn{5}{|l|}{ Burseraceae } \\
\hline Commiphora leptophloeos (Mart.) J.B.Gillet & Umburana & 1.14 & 0.60 & 0.55 \\
\hline
\end{tabular}


Trindade et al. - Availability and Use of Woody Plant Resources in Two Areas 323 of Caatinga in Northeastern Brazil

\begin{tabular}{|c|c|c|c|c|}
\hline Species & Common name & $\mathbf{U V}_{\text {general }}$ & $\mathbf{U V}_{\text {actual }}$ & $U \mathbf{V}_{\text {potential }}$ \\
\hline \multicolumn{5}{|l|}{ Capparaceae } \\
\hline Cynophalla flexuosa (L.) J.Prese & Feijão-brabo & 0.98 & 0.40 & 0.57 \\
\hline Neocalyptrocalyx longifolium (Mart.) Cornejo \& Iltis & Icó & 0.14 & 0.05 & 0.10 \\
\hline \multicolumn{5}{|l|}{ Celastraceae } \\
\hline Maytenus rígida Mart. & Bom-nome & 0.40 & 0.10 & 0.31 \\
\hline \multicolumn{5}{|l|}{ Combretaceae } \\
\hline Thiloa glaucocarpa (Mart.) Eichler & João-mole & 0.33 & 0.17 & 0.17 \\
\hline \multicolumn{5}{|l|}{ Euphorbiaceae } \\
\hline Cnidoscolus quercifolius Pohl & Favela & 0.21 & 0.05 & 0.17 \\
\hline Croton blanchetianus Baill. & Marmeleiro & 2.31 & 1.38 & 0.93 \\
\hline Croton rhamnifolius Kunth. & Velame & 0.07 & 0.07 & 0.00 \\
\hline Jatropha mollissima (Pohl) Baill. & Pinhão-bravo & 0.24 & 0.17 & 0.07 \\
\hline Jatropha ribifolia (Pohl) Baill. & Pinhão-manso & 0.02 & 0.02 & 0.00 \\
\hline Manihot dichotoma Ule. & Maniçoba & 0.79 & 0.45 & 0.33 \\
\hline Sapium lanceolatum (Müll.Arg.) Huber & Burra-leiteira & 0.14 & 0.10 & 0.05 \\
\hline \multicolumn{5}{|l|}{ Fabaceae } \\
\hline Amburana cearensis (Allemão) A.C.Sm. & Cumarú & 1.00 & 0.64 & 0.36 \\
\hline Anadenanthera colubrina (Vell.) Brenan & Angico & 0.62 & 0.38 & 0.24 \\
\hline Bauhinia cheilantha (Bong.) Steud. & Mororó & 0.83 & 0.45 & 0.38 \\
\hline Enterolobium timbouva Mart. & Tambor & 0.19 & 0.07 & 0.12 \\
\hline Erythrina velutina Willd. & Mulungú & 0.35 & 0.19 & 0.16 \\
\hline Hymenaea sp. & Jatobá & 0.93 & 0.60 & 0.33 \\
\hline Libidibia ferrea (Mart. ex Tul.) L.P.Queiroz & Jucá & 1.10 & 0.38 & 0.71 \\
\hline Luetzeburgia sp. & Pau-pedra & 0.14 & 0.02 & 0.12 \\
\hline Mimosa sp. & Jurema-branca & 1.52 & 0.83 & 0.69 \\
\hline Mimosa tenuiflora (Willd.) Poir. & Jurema-preta & 1.98 & 1.02 & 0.95 \\
\hline Piptadenia sp. & Amorosa-preta & 0.05 & 0.02 & 0.02 \\
\hline Piptadenia stipulacea (Benth.) Ducke & Amorosa-branca & 0.02 & 0.00 & 0.02 \\
\hline Pithecellobiun diversifolium Benth. & Espinheiro & 0.05 & 0.00 & 0.05 \\
\hline Poincianella pyramidalis Tul. & Catingueira & 3.45 & 2.29 & 1.17 \\
\hline Senna spectabilis (DC.) H.S.Irwin \& Barneby & Canafistula & 0.36 & 0.17 & 0.19 \\
\hline Unidentified & Jurema-cariri & 0.02 & 0.00 & 0.02 \\
\hline \multicolumn{5}{|l|}{ Lauraceae } \\
\hline Unidentified & Louro & 0.52 & 0.36 & 0.17 \\
\hline \multicolumn{5}{|l|}{ Malpighiaceae } \\
\hline Byrsonima sp. & Murici & 0.10 & 0.00 & 0.10 \\
\hline \multicolumn{5}{|l|}{ Malvaceae } \\
\hline Ceiba glaziovii (Kuntze) K.Schum. & Barriguda & 0.04 & 0.04 & 0.00 \\
\hline \multicolumn{5}{|l|}{ Meliaceae } \\
\hline Cedrela odorata L. & Cedro & 0.17 & 0.07 & 0.1 \\
\hline \multicolumn{5}{|l|}{ Myrtaceae } \\
\hline Eugenia uvalha Cambess. & Ubaia & 0.10 & 0.05 & 0.05 \\
\hline
\end{tabular}




\begin{tabular}{|c|c|c|c|c|}
\hline Species & Common name & $\mathbf{U V}_{\text {general }}$ & $\mathbf{U V}_{\text {actual }}$ & $\mathbf{U V}_{\text {potential }}$ \\
\hline \multicolumn{5}{|l|}{ Olacaceae } \\
\hline Ximenia americana L. & Ameixa & 0.29 & 0.19 & 0.1 \\
\hline \multicolumn{5}{|l|}{ Rhamnaceae } \\
\hline Ziziphus joazeiro Mart. & Juá & 3.98 & 1.93 & 2.05 \\
\hline \multicolumn{5}{|l|}{ Rubiaceae } \\
\hline Genipa americana L. & Jenipapo & 0.02 & 0.00 & 0.02 \\
\hline \multicolumn{5}{|l|}{ Sapotaceae } \\
\hline Sideroxylon obtusifolium (Roem. \& Schult.) T.D.Penn. & Quixabeira & 1.12 & 0.62 & 0.50 \\
\hline \multicolumn{5}{|l|}{ Urticaceae } \\
\hline Cecropia sp. & Imbaúba & 0.02 & 0.00 & 0.02 \\
\hline \multicolumn{5}{|l|}{ Unidentified } \\
\hline Unidentified 1 & Limãozinho & 0.05 & 0.05 & 0.00 \\
\hline Unidentified 2 & Louro-branco & 0.05 & 0.00 & 0.05 \\
\hline
\end{tabular}

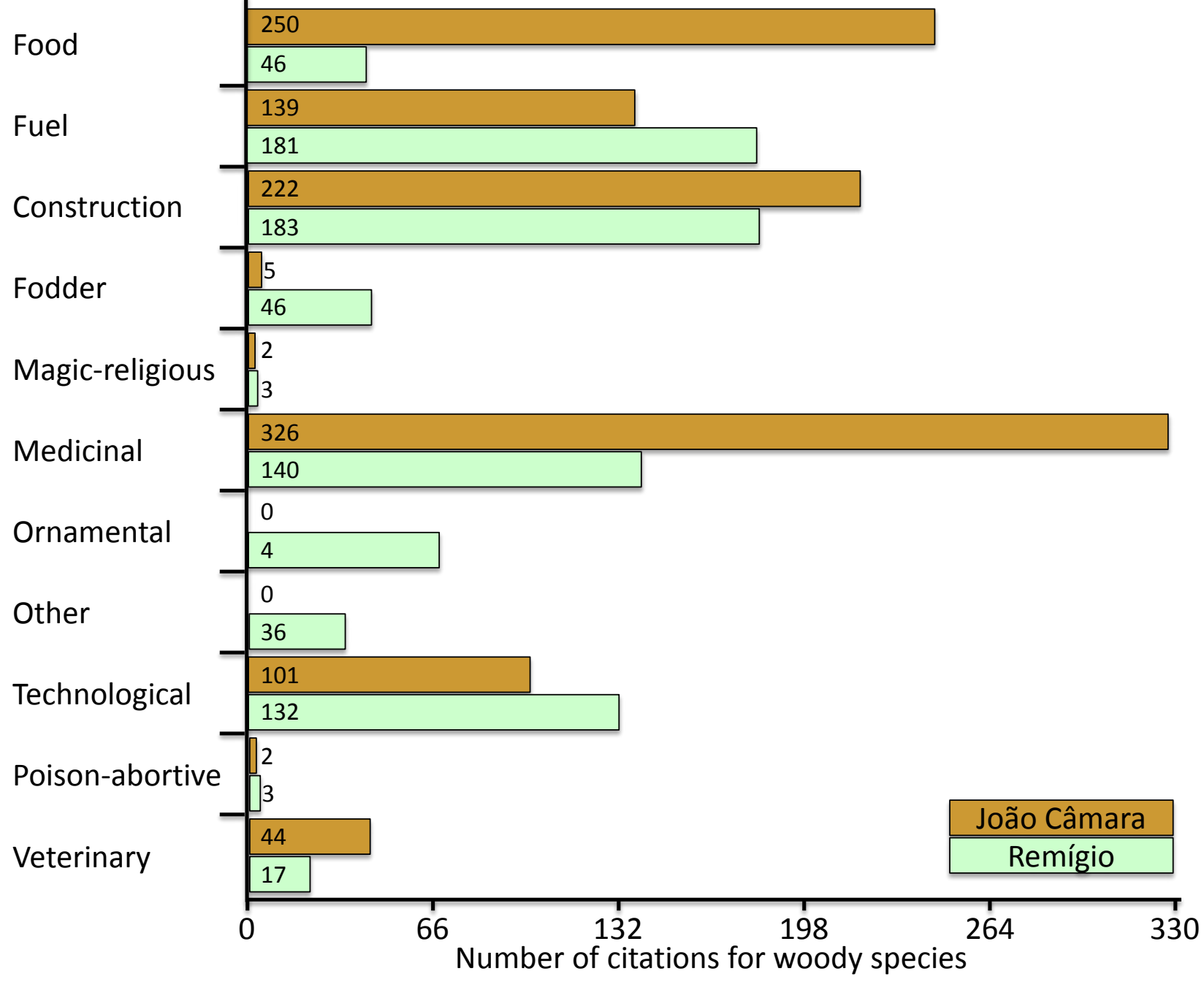

Figure 4. Representation of the number of citations per use category in the communities of Mato Grande, João Câmara, Rio Grande do Norte, and Coelho, Remígio, Paraíba, northeastern Brazil. 


\section{Trindade et al. - Availability and Use of Woody Plant Resources in Two Areas 325 of Caatinga in Northeastern Brazil}

The relative importance of species from the municipality of João Câmara indicated preference for some species over others. For instance, jurema-preta ( $M$. tenuiflora), umbu (Spondias tuberosa Arruda), pereiro ( $A$. pyrifoli$u m$ ), ameixa ( $X$. americana), canelinha-do-mato (Croton zehntneri Pax \& K.Hoffm.), quixabeira (S. obtusifolium), and juazeiro (Z. joazeiro) all had $U_{\text {actual }}$ equal or higher than 1.00 (Table 2).

In Remígio, the more used species were pereiro ( $A$. pyrifolium), catingueira ( $P$. pyramidalis), juazeiro ( $Z$. joazeiro), baraúna ( $S$. brasiliensis), marmeleiro (C. blanchetianus), aroeira ( $M$. urundeuva), and jurema-preta $(M$. tenuiflora). It is noteworthy that the most important species in the two municipalities are pereiro, juazeiro, and jurema-preta. The UV of these species varied from 1.00 to 4.86 (Table 5).

The Pearson correlation coefficient analyses among the three types of UVs showed that in the community of Mato Grande the correlations were positive. All UV were correlated among themselves: UV $V_{\text {general }}$ with $\mathrm{UV}_{\text {actual }}(r=$ $0.9815 \mathrm{e} ; \mathrm{p}<0.0001)$; UV $\mathrm{general}_{\text {with }} \mathrm{UV}_{\text {potential }}(r=0.6562 \mathrm{e}$; $\mathrm{p}<0.0009)$; and $U V_{\text {actual }}$ with $U V_{\text {potential }}(r=0.4995 e ; p<$ 0.0179).

\section{Hypothesis of ecological apparency}

The phytosociological parameters were positively correlated with the UVs. In João Câmara, it was significant between UV $\mathrm{general}$ and dominance ( $r \mathrm{~s}=0.49 ; \mathrm{p}<0.02$ ), and $U V_{\text {actual }}$ and dominance $(r s=0.43 ; p<0.04)$. When the use categories are analyzed separately, the only one showing positive significant correlation was technological. Also, it was significant between UV potential and dominance ( $\mathrm{rs}=$ $0.60 ; p<0.03$ ). In Remígio the ecological apparency hypothesis was not supported.

\section{Discussion}

\section{Relative importance vs. availability}

In contrast to trends found in studies conducted in humid forests, those conducted in dry forests showed diverse results, some of them agreeing with predictions of the ecological apparency hypothesis, but others not (Albuquerque \& Lucena 2005, Lucena et al. 2007, 2012a,b, Ribeiro et al. 2013).

This study found positive correlations only in João Câmara when correlation of phytosociological parameters and use values was analyzed. Discussions about the influence of the usual methods applied to the apparency hypothesis test have already been exposed by Lucena et al. (2012a) to clarify whether the responses found are artifacts of the methods used, mainly through permanent and semi-permanent sampling as seen in previous pub- lished works. We used a method (point-centered quarter) that was not previously used for humid and dry forests for sampling phytosociological parameters. This method was shown to be satisfactory for sampling to test an apparency hypothesis according to the data results.

In João Câmara we found significant positive correlations between $U V_{\text {general }}$ and $U V_{\text {actual }}$ with the relative dominance, similar to previous studies conducted in different areas of caatinga. In the state of Pernambuco, Lucena et al. (2007) did not find distinctions among uses reported but significant correlations between UV and relative frequency, but only in the sites far apart from the communities. In state of Paraíba, Lucena et al. (2012a) found correlations among all types of use value with the relative dominance and basal area. Similar results were also described by Ribeiro (2013) and Lucena (2012b), who found positive correlations between UV $V_{\text {general }}$ and $U V_{\text {actual }}$ with relative dominance. In addition, these authors found supporting evidence for an ecological apparency hypothesis, particularly among timber product species.

Ribeiro et al. (2013), using similar parameters as in our study, found positive correlations for the categories fuel, construction, and technological uses for all the phytosociological parameters in the municipality of Solânea. Previous studies conducted in caatinga also recorded positive correlations between use categories and local availability, particularly those for timber use (Lucena et al. 2007, 2012a,b).

Compared to other studies conducted in caatinga, our current study found that the technological category was the only one with significant correlations $(p \leq 0,05)$, particularly between $U_{\text {potential }}$ and dominance. This is a use category mainly associated with timber, in which species are utilized for producing wood handles of several tools (machetes, planting hoes, pickaxes, sickles, and others). Wood is also used for producing broomsticks, wood spoons, and furniture. In this category we also grouped various uses of tree products in hunting (latex for trapping birds), poisons (toxic leaves/cortex of Manihot carthaginensis (Jacq.) Müll.Arg. which are prepared for poisoning birds), bullet cases of a shotgun (fiber cortex of Bauhinia cheilantha (Bong.) Steud.), and sexual stimulants (syrup with several species).

Remígio differs from João Câmara in that there were no significant correlations observed. Previously, negative results were reported by Albuquerque and Lucena (2005), who showed exactly the opposite result from the predictions of an ecological apparency hypothesis: the species locally more important were those rarer. Ferraz et al. (2006) and Sousa (2011) found that correlations were not significant. Then, what does explain the positive correlations reported for woody plant resources in caatinga? Ga- 
leano (2000) considers that ecological factors may drive the use of plant species.

Specific characteristics of the study areas such as elevation range and climatic and edaphic particularities, as well as vegetation composition and other geographic features may all be influencing factors. The municipalities studied here are in different elevation ranges; Remígio is on a $600 \mathrm{~m}$ plateau while João Câmara is in a geographic depression in lowlands. Each area is in a different ecoregion (Planalto of the Borborema and Depressão Sertaneja Setentrional), with important climatic, edaphic, and topographic differences. Comparable floristic composition is low with the Jaccard similarity coefficient estimating nearly $35 \%$ of similarity, although similarity of useful species was $41 \%$ which is not low.

In caatinga arboreal plant resources are available most of the year despite the marked climatic seasonality of the region; therefore, the potential use of arboreal species is likely more expressive than others. The frequency of this type of resource generates a special cause and effect relationship that reinforces uses. Cultural factors are also definitely important since they may influence the relative importance of use categories and species, because the demand of floristic resources for the Sertanejo people is not the same as for peoples living in other biomes.

IIt is possible that patterns observed are related to people looking for, and using, plant species according to pre-established models in their community. For instance, species already recognized because of their efficacy may be in greater demand, independently of their availability in the forest. Also, preference for woody plants may be influenced by their easy access, as it has been reported in studies carried out in caatinga.

So far, studies testing the apparency hypothesis of nontimber resources have not found significant correlations between their use and abundance in dry forests. Almeida et al. (2010) tested the hypothesis with medicinal plants, and their results do not support the predictions. Balcázar (2012) conducted studies in another dry vegetation type of Brazil (the cerrado biome), testing the apparency hypothesis with medicinal plants and finding similarly as Almeida et al. (2010). According to Tunholi et al. (2013) the timber resources categories in cerrado are not as important as in caatinga since in the later plants are of low height and twisted, which limits use for construction.

The plant species and families of wide distribution and high use value recorded in this study were also referred to in other studies in caatinga (e.g., Albuquerque et al. 2006, Albuquerque \& Oliveira 2007, Ferraz et al. 2006, Guerra et al. 2012, Lucena et al. 2007, Monteiro et al. 2006, Pereira et al. 2002). In these cases, C. blanchetianus (Euphorbiaceae) and all species of Fabaceae studied were representative in terms of the number of individual plants sampled in the two communities studied. This pattern could be an indication that the most important plant species and families for the Sertanejos people are consequently under higher management intensity.

\section{Implications for conservation}

According to their UVs, 10 species were outstanding in the two communities: $M$. tenuiflora, S. tuberosa, A. pyrifolium, $X$. americana, C. zehntneri, S. obtusifolium, Z. joazeiro, $P$. pyramidalis, S. brasiliensis, and C. blanchetianus. With the exception of $C$. zehntneri, which is used as medicine and food, the remaining species are used as timber resources for fuel, construction, and technological categories, all of them implying cutting the plant.

Several plant species used were less represented in the phytosociological sampling, probably as an expression of naturally restricted ecological distribution in the area or because of progressive scarcity resulting from bad management. In Remígio, seven species had low representation: Myracrodruon urundeuva Allemão (7 individual plants), $M$. tenuiflora (7), $X$. americana (4), Libidibia ferrea (Mart. ex Tul.) L.P.Queiroz (2), Schinopsis brasiliensis Engl. (2), S. tuberosa (2), and S. obtusifolium (0), all of them with use values near 1 . In João Câmara, these were the cases of six species: $A$. cearensis ( 9 individual plants), S. obtusifolium (7), M. urundeuva (2), S. tuberosa (1), C. zehntneri $(0)$, and $X$. americana $(0)$.

The case of $M$. tenuiflora is particularly important because there is a high demand, it is heavily extracted for fuel wood and for charcoal production, and it is frequently commercialized as well as used for construction. Although the phytosociological sampling identified this species as well represented (90 individual plants), this species deserves special attention in management and conservation programs.

The utilitarian similarity of several species documented in this study is similar to other projects conducted in caatinga ecosystem. Cases of plants frequently used as medicines include: $A$. cearensis (cumarú), C. blanchetianus (marmeleiro), M. urundeuva (aroeira), S. brasiliensis (baraúna), $S$. obtusifolium (quixabeira), and $X$. americana (ameixa) (Albuquerque et al. 2005, Cartaxo et al. 2010, Lucena et al. 2007, 2012a,b, Ribeiro et al. 2013, Roque et al. 2010). In other use categories such as timber (construction, fuel, and technological), several species are similarly used: $M$. urundeuva (aroeira), M. tenuiflora (jurema-preta), S. tuberosa (umbu), C. leptophloeos (imburana), Sapium glandulosum (L.) Morong (burraleiteira), and A. pyrifolium (pereiro) (Albuquerque et al., 2009), among others.

It was also found that distribution of useful plant species was not homogeneous in composition and structure. Some species were recorded only in the most distant sites 


\section{Trindade et al. - Availability and Use of Woody Plant Resources in Two Areas 327 of Caatinga in Northeastern Brazil}

from the villages; others with less restricted distribution were recorded dispersed in several sites of the forest. In the floristic inventories from the two study regions, $C$. blanchetianus (marmeleiro), $P$. pyramidalis (catingueira), $P$. stipulacea (jurema-branca), and $Z$. joazeiro (joazeiro) were widely recorded, mainly in sites near the villages. Similar results were recorded in other areas of caatinga (Guerra et al. 2012, Ribeiro et al. 2013, Santos et al. 2009), where these species were also reported to be abundant in anthropic areas. In João Câmara, in addition to the species referred to above, we recorded $M$. tenuiflora (jurema-preta), and in Remígio Jatropha mollissima (Pohl) Baill. (pinhão-bravo).

High numbers of species with restricted distribution were also recorded in the two communities studied. The cases of M. urundeuva (aroeira) and C. leptophloeos (imburana) were particularly relevant. These species were sampled in sites distant from villages in good conserved fragments. Anadenanthera colubrina (angico), A. cearensis (cumarú), and $S$. obtusifolium (quixabeira) had low frequency in João Câmara and were also found in sites distant to the villages. In Remígio, S. brasiliensis (baraúna) and $X$. americana (ameixa) were recorded in similar situations. The distribution pattern of these species can be explained because of their ecological characteristics of dispersion, reproduction, resilience (capacity of maintenance in absence of favorable conditions), fragility of saplings, and regeneration capacity, among others (Barbosa 2003).

In both regions, a large number of species were mentioned that have high use values $\left(U_{\text {actual }}\right)$ and that are considered at risk of extinction in the official lists. This is the case for $A$. cearensis, $A$. colubrina, $M$. urundeuva, and S. brasiliensis (IUCN 2001, MMA 2008).

\section{Conclusions}

To understand the dynamics of utilization of useful plant species in the Brazilian semi-arid zones and other dry forest types, more research is needed. Studies conducted until present are few and concentrated in few states. More attention should also be directed to ecological studies of particular species in order to make clearer the resilience profile of those plant resources under higher extractivist pressure and thus understand their susceptibility to local extinction. Studies to identify priority species for conservation are crucial for maintaining the biological diversity in the studied areas and for the caatinga biome as a whole.

Information on availability and management of useful species may help us understand about extractivist pressure and the susceptibility of the most fragile species in the studied areas (Albuquerque 2010, Lucena et al. 2012a, 2013, Sá e Silva et al. 2009).
The communities studied in the region of Mato Grande, Rio Grande do Norte, and Coelho, Paraíba, have great knowledge about the woody vegetation of caatinga. The utilization of timber resources in João Câmara supported the hypothesis of ecological apparency but only for the category of technological use, in which the correlation between use and ecological parameters was significantly positive.

These results, together with those reported previously for caatinga, suggest the existence of a trend of utilization of timber resources according to their availability. Until present this trend has not been described among non-timber forest resources. It is however necessary to enhance ethnobiological and ecological studies in caatinga and other dry forests in order to obtain more information about the potential resources of these biomes and their vulnerability to extractivism.

Through association of use value of plant species, establishing differences between effective use and local availability was possible and allowed for the identification of species requiring particular attention for conservation. These are highly demanded species that are in the official lists of endangered species: $A$. cearensis (cumaru), $A$. colubrina (angico), M. urundeuva (aroeira), and S. brasiliensis (baraúna).

Since this was the first study in Rio Grande do Norte, new tests of the apparency hypothesis are still necessary, particularly in areas of caatinga. It is also pertinent to say that this is the first study using the point-centered quarter method to test the apparency hypothesis in tropical dry forest, and it was an effective sampling method. We recommend the use of this method for further studies in order to compare appropriately the results.

Finally, considering all these aspects, we consider it necessary to enhance ethnobiological and ecological research in caatinga and cerrado ecosystems, in order to contribute to design strategies for their sustainable management.

\section{Acknowledgments}

We would like to thank the residents of Cauaçu and Coelho communities for their help during this. The first author is grateful to Coordenacão de Aperfeiçoamento de Pessoal de Nível Superior (CAPES) for fellowships. We are also grateful to the members of the Laboratory of Ethnobiology at the Federal University from Paraíba and to the members of herbarium UFRN at the Universidade Federal do Rio Grande do Norte by their help in fieldwork and during the writing of this article. 


\section{Literature Cited}

Albuquerque, U.P., L.H.C. Andrade \& A.C.O. Silva. 2005. Use of plant resources in a seasonal dry forest (Northeastern Brazil). Acta Botanica Brasílica 19:1-16. dx.doi. org/10.1590/s0102-33062005000100004

Albuquerque, U.P. \& R.F.P. Lucena. 2005. Can apparency affect the use of plants by local people in tropical forests? Interciencia 30:506-511.

Albuquerque, U.P., R.F.P. Lucena, J.M. Monteiro, A.T.N. Florentino \& C.F.C.B.R. Almeida. 2006. Evaluating two quantitative ethnobotanical techniques. Ethnobotany $R e-$ search and Applications 4:51-60.

Albuquerque, U.P. \& R.F. Oliveira. 2007. Is the use-impact on native caatinga species in Brazil reduced by the high species richness of medicinal plants? Journal of Ethnopharmacology 113:156-170. dx.doi.org/10.1016/j. jep.2007.05.025

Albuquerque, U.P., T.A.A. Sousa, M.A. Ramos, V.T. Nascimento, R.F.P. Lucena, J.M. Monteiro, N.L. Alencar \& A.E. Lima. 2009. How ethnobotany can aid biodiversity conservation: Reflections on investigations in the semi-arid region of NE - Brazil. Biodiversity and Conservation 18:127150. $\underline{\mathrm{dx} . \text { doi.org/10.1007/s10531-008-9463-8 }}$

Albuquerque, U.P. 2010. Etnobotânica aplicada à conservação da biodiversidade. Pp. 351-364 in Métodos e Técnicas na Pesquisa Etnobiológica e Etnoecológica. Edited by U.P. Albuquerque, R.F.P. Lucena \& L.V.F.C. Cunha. Núcleo de Publicações em Ecologia e Etnobotânica Aplicada, Recife, Brazil.

Almeida, C.F.C.B.R., M.A. Ramos, E.L.C. Amorim \& U.P. Albuquerque. 2010. A comparison of knowledge about medicinal plants for three rural communitieis in the semi-arid region of northeast of Brazil. Journal of Ethnopharmacology 127:674-684. dx.doi.org/10.1016/j.jep.2009.12.005

Alves, J.J.A., M.A. Araújo \& S.S. Nascimento. 2009. Degradação da caatinga: Uma investigação ecogeográfica. Caatinga 22:126-135.

Araújo, E.L. \& E.M.N. Ferraz. 2010. Amostragem da vegetação nos estudos etnobotânicos. Pp. 223-253 in Métodos e Técnicas na Pesquisa Etnobiológica e Etnoecológica. Edited by U.P. Albuquerque, R.F.P. Lucena \& L.V.F.C. Cunha. Núcleo de Publicações em Ecologia e Etnobotânica Aplicada, Recife, Brazil.

Ayantunde, A.A., P. Hiernaux, M. Briejer, H. Udo \& R Tabo. 2009. Uses of local plant species by agropastoralists in south-western-Niger. Ethnobotany Research and Applications 7:53-66.
Ayres, M., M. Ayres Júnior, D.L. Ayres \& A.A. Santos. 2007. BIOESTAT - Aplicações estatísticas nas áreas das ciências bio-médicas. Ong Mamiraua, Belém, Pará, Brazil.

Balcázar, A. L. 2012. Hipótes da Aparência na Dinâmica do Uso de Plantas Medicinais na Floresta Nacional do Araripe (Ceará, Nordeste do Brasil). Ph.D. dissertation. Rural Federal University of Pernambuco, Recife, Brazil.

Barbosa, D.C.A. 2003. Estratégias de germinação e crescimento de espécies lenhosas da caatinga com germinação rápida. Pp. 625-656 in Ecologia e Conservação da Caatinga. Edited by I.R. Leal, M. Tabarelli \& J.M.C. Silva. Federal University of Pernambuco, Recife, Brazil.

Cartaxo, S.L., M.M.A. Souza \& U.P. Albuquerque. 2010. Medicinal plants with bioprospecting potential used in semi-arid northeastern Brazil. Journal of Ethnopharmacology 131:326-342. dx.doi.org/10.1016/j.jep.2010.07.003

Costa, C.R., F.S. Araújo \& L.W. Lima-Verde. 2007. Flora and life form spectrum in an area of a thorn deciduous woodland (Caatinga) of northeastern Brazil. Journal of Arid Environments 68:237-247. dx.doi.org/10.1016/j. jaridenv.2006.06.003

Cottam, G. \& J.T. Curtis. 1956. The use of distance measures in phytosociological sampling. Ecology 37:451460. dx.doi.org/10.2307/1930167

Cunha, L.V.F.C. \& U.P. Albuquerque. 2006. Quantitative ethnobotany in an Atlantic forest fragment of northeastern Brazil: Implication to conservation. Environmental Monitoring and Assessment 114:1-25. dx.doi.org/10.1007/ $\underline{\mathrm{s} 10661-006-1074-9}$

Feeny, P. 1976. Plant apparency and chemical defense. Pp. 1-40 in Biochemical Interactions Between Plants and Insects. Recent Advances in Phytochemistry. Edited by J.W. Wallace \& R.L. Nansel. Plenum Press, New York, New York, U.S.A. dx.doi.org/10.1007/978-1-4684-2646$\underline{51}$

Ferraz, J.S.F., U.P. Albuquerque \& I.M.J. Meunier. 2006. Valor do uso e estrutura da vegetação lenhosa às margens do Riacho do Navio, Floresta, PE, Brazil. Acta Botanica Brasílica 20(1):25-134. dx.doi.org/10.1590/S0102$\underline{33062006000100012}$

Galeano, G. 2000. Forest use at the Pacific coast of Chocó, Colômbia: A quantitative approach. Economic Botany 54(3):358-376. dx.doi.org/10.1007/BF02864787

Guerra, N.M., J.E.S. Ribeiro, T.K.N. Carvalho, K.M. Pedrosa, L.P. Felix \& R.F. P. Lucena. 2012. Usos locais de espécies vegetais nativas em uma comunidade rural no 


\section{Trindade et al. - Availability and Use of Woody Plant Resources in Two Areas 329 of Caatinga in Northeastern Brazil}

semiárido nordestino (São Mamede, Paraíba, Brasil). Revista de Biologia e Farmacia - Biofar, Edição especial:184-211.

IBGE. 2010. Instituto Brasileiro de Geografia e Estatística. Censo Demográfico. www.ibge.gov.br/cidades. Accessed 20 August 2013.

IBGE. 2012. Instituto Brasileiro de Geografia e Estatística. Ensino - Matrículas, Docentes e Rede Escolar. cod. ibge.gov.br/AZW6. Acessed 15 August 2013.

IUCN. 2001. Red List Categories and Criteria, Version 3.1. Prepared by the International Union for Conservation of Nature, Species Survival Commission. International Union for Conservation of Nature, Gland, Switzerland.

Jiménez-Escobar, N.D. \& J.O. Rangel-Ch. 2012. La abundancia, la dominancia y sus relaciones con el uso de la vegetación arbórea en la bahía de cispatá, caribe colombiano: Abundance, dominance and their relationship to use of tree species in Cispatá Bay, Caribbean region of Colombia. Caldasia 34(2):347-366.

La Torre-Cuadros, M.A. \& G.A. Islebe. 2003. Traditional ecological knowledge and use of vegetation in southeastern México: A case study from Solferino, Quintana Roo. Biodiversity and Conservation 12:2455-2476. dx.doi. org/10.1023/A:1025861014392

Lawrence, A., O.L. Phillips, A. Reategui, M. Lopez, S. Rose, D. Wood \& A.J. Farfan. 2005. Local values for harvested forest plants in Madre de Dios, Peru: Towards a more contextualised interpretation of quantitative ethnobotanical data. Biodiversity and Conservation 14:45-79. dx.doi.org/10.1007/s10531-005-4050-8

Lucena, R.F.P., E.L. Araújo \& U.P. Albuquerque. 2007. Does the local availability of woody Caatinga plants (Northeastern Brazil) explain their use value? Economic Botany 61(4):347-361. dx.doi.org/10.1663/00130001(2007)61[347:DTLAOW]2.0.CO;2

Lucena, R.F.P., V.T. Nascimento, E.L. Araújo \& U.P. Albuquerque. 2008. Local uses of native plants in na area of Caatinga vegetation (Pernambuco, NE Brazil). Ethnobotany Research and Applications 6:3-13.

Lucena, R.F.P., P.M. Medeiros, E.F. Araújo, A.G.C. Alves \& U.P. Albuquerque. 2012a. The ecological apparency hypothesis and the importance of useful plants in rural communities from Northeastern Brazil: An assessment based on use value. Journal of Environmental Management 96:106-115. dx.doi.org/10.1016/j.jenvman.2011.09.001

Lucena, R.F.P., A.P. Leite, K.M. Pedrosa, C.M. Lucena, C.F.A. Vasconcelos Neto \& J.P.O. Ribeiro. 2012b. O uso de species locais no Vale do Piancó pode ser explica- do pela sua disponibilidade local? Revista de Biologia e Farmacia - Biofar, Edição especial:55-71.

Lucena, R.F.P., C.M. Lucena, E.L. Araújo, A.G.C. Alves \& U.P. Albuquerque. 2013. Conservation priorities of useful plants from different techniques of collection and analysis of ethnobotanical data. Anais da Academia Brasileira de Ciências 85:169-186. dx.doi.org/10.1590/S0001$\underline{37652013005000013}$

MMA. 2008. Lista das Espécies da Flora Brasileira Ameaçadas de Extinção. Instrução Normativa no. 6 de 23 de Setembro de 2008. Ministerio do Meio Ambiente, Brasília, Brazil.

Monteiro, J.M., C.F.C.B.R. Almeida, U.P. Albuquerque, R.F.P. Lucena, A.T.N. Florentino \& R.L.C. Oliveira. 2006. Use and traditional management of Anadenanthera colubrina (Vell.) Brenan in the semi-arid region of northeastern Brazil. Journal of Ethnobiology and Ethnomedicine 2:1-7. dx.doi.org/10.1186/1746-4269-2-6

Mutchnick, P.A. \& B.C. McCarthy. 1997. An ethnobotanical analysis of the tree species common to the subtropical moist forests of the Petén, Guatemala. Economic Botany 51:158-183. dx.doi.org/10.1007/BF02893110

Nimer, E. 1989. Climatologia do Brasil. Departamento de Recursos Naturais e Estudos Ambientais, Rio de Janeiro, Brazil.

Pereira, I.M., L.A. Andrade, M.R.V. Barbosa \& E.V.S.B. Sampaio. 2002. Composição florística e análise fitossociológica do componente arbustivo-arbóreo de um remanescente florestal no agreste paraibano. Acta Botanica Brasilica 16:357-369. dx.doi.org/10.1590/S0102$\underline{33062002000300009}$

Phillips, O. \& A.H. Gentry. 1993a. The useful plants of Tambopata, Peru: I. Statistical hypotheses test with new quantitative technique. Economic Botany 47:15-32. dx.doi.org/10.1007/BF02862203

Phillips, O. \& A.H. Gentry. 1993b. The useful plants of Tambopata, Peru: II. Additional hypothesis testing in quantitative ethnobotany. Economic Botany 47:33-43. dx.doi.org/10.1007/BF02862204

Prado, D.E. 2003. As caatingas da América do Sul. Pp. 3-73 in Ecologia e Conservação da Caatinga. Edited by I.R. Leal, M. Tabarelli, J.M.C. Silva. Universitária da UFPE, Recife, Brazil.

Rhoades, D.F. \& R.G. Cates. 1976. Toward a general theory of plant antiherbivore chemistry. Pp. 169-213 in Biochemical Interactions Between Plants and Insects. Recent Advances in Phytochemistry. Edited by J.W. Wal- 
lace \& R.L. Nansel. Plenum Press, New York, New York, U.S.A. dx.doi.org/10.1007/978-1-4684-2646-5 4

Ribeiro, J.E.S. 2013. A Hipótese da Aparência Ecológica e Importância de Plantas Uteis: Testando diferentes valores de uso. Monograph. Federal University of Paraíba, Bananeiras, Paraíba, Brazil.

Ribeiro, J.P.O., T.K.N. Carvalho, J.E.S. Ribeiro, R.F. Sousa, J.R.F. Lima, C.A.B. Alves, J.G. Jardim \& R.F.P. Lucena. 2014. Can ecological apparency explain the use of plant species in the semi-arid depression of Northeastern Brazil? Acta Botanica Brasilica 28(3):476-483. dx.doi. org/10.1590/0102-33062014abb2758

Roque, A.A., R.M. Rocha \& M.I.B. Loiola. 2010. Uso e diversidade de plantas medicinais da caatinga na comunidade rural de Laginhas, município de Caicó, Rio Grande do Norte (nordeste do Brasil). Revista Brasileira de Plantas Medicinais 12:31-42. dx.doi.org/10.1590/S1516$\underline{05722010000100006}$

Rossato, S.C., H.F. Leitão-Filho \& A. Begossi. 1999. Ethnobotany of Caiçaras of the Atlantic Forest Coast (Brazil). Economic Botany 53:387-395. dx.doi.org/10.1007/ BF02866716

Sá e Silva, I.M.M., L.C. Marangon, N. Hanazaki \& U.P. Albuquerque. 2009. Use and knowledge of fuelwood in three rural caatinga (dryland) communities in NE Brazil. Environment, Development and Sustainability 11:833852. dx.doi.org/10.1007/s10668-008-9146-3

Santos, L.L., M.A. Ramos, S.I. Silva, M.F. Sales \& U.P. Albuquerque. 2009. Caatinga ethnobotany: Anthropogenic landscape modification and useful species in Bra- zil's semi-arid northeast. Economy Botany 63:363-374. dx.doi.org/10.1007/s12231-009-9094-3

Shepherd, G.J. 2009. FITOPAC 2.1 (preliminary version). Departamento de Biologia Vegetal, Universidade Estadual de Campinas, Campinas, São Paulo, Brazil.

Sousa, R.F. 2011. A Aparência Ecológica pode Explicar a Utilização de Espécies Uteis em uma Comunidade Rural na Região do Seridó Paraibano? Monograph. Federal University of Paraíba, Areia. Paraíba, Brazil.

Spradley, J.P. \& D.W. McCurdy. 1972. The Cultural Experience. Ethnography in complex society. Science Research Associates Inc, Chicago, Illinois, U.S.A.

Stagegaard, J., M. Sørensen \& L.P. Kvist. 2002. Estimations of the importance of plant resources extracted by inhabitants of the Peruvian Amazon flood plains. Perspectives in Plant Ecology, Evolution and Systematics 5(2):103-122. dx.doi.org/10.1078/1433-8319-00026

Thomas, E., I. Vandebroek \& P. Van Damme. 2009. Valuation of forest and plant species in indigenous territory and national Park Isiboro-Sécure, Bolivia. Economic Botany 63:229-241. dx.doi.org/10.1007/s12231-009-9084-5

Tunholi, V.P., M.A. Ramos \& A. Scariot. 2013. Availability and use of woody plants in a agrarian reform settlement in the cerrado of the state of Goiás, Brazil. Acta Botanica Brasilica 27(3):604-612. dx.doi.org/10.1590/S0102$\underline{33062013000300018}$

Velloso, A.L., E.V.S.B. Sampaio \& F.G.C. Pareyn. 2002. Ecorregiões Propostas para o Bioma Caatinga. The Nature Conservancy do Brasil, Associação Plantas do Nordeste, Recife, Brazil. 